\title{
VAJdA Mihály \\ Ki tudja, miféle könyv, és miről szól \\ a Nincstelenek
}

Heller Ágnes Olvasónaplójában szerepel Borbély Szilárd Nincstelenekje. ${ }^{1}$ A rövid szövegben tulajdonképpen csak azt fejti ki, hogy miért nem szerette ő ezt a könyvet. Nem, tévedek. Ezt csak leszögezi, azzal, hogy - kétszer is - nem ért valamit. Egyszer azt, hogy ő „mindenkivel” ellentétben nem lelkesedett ezért a könyvért. „Mindenki lelkesedett ezért a könyvért. Senki sem érti, hogy én miért nem." (A bejegyzés első két mondata). Másodszor azt nem érti, hogy mások miért szerették a könyvet. „Nem igazán értem, hogy mit szerettek ezen a könyvön mások oly nagyon. Azt viszont tudom, hogy én nem vagyok »mások «"” (A bejegyzés utolsó két mondata). Olvasónapló-bejegyzésről van szó, nem elemzésről vagy kritikáról. Nem érdemes rá sok szót vesztegetni. Mások lelkesedtek a könyvért, Ágnes nem. Mások nagyon szerették, ő meg nem. A dolognak nincs jelentősége. Itt abba is kellene hagynom az írást. Le is tenném a „tollat”, ha Heller a könyvről szóló néhány bekezdésben egyszerüen leszögezné, hogy elolvasta Borbély Szilárd utolsó munkáját - tudta, hogy az utolsó, azt is tudta, hogy Szilárd öngyilkos lett -, s nem tetszett neki. Biztos ez? Pontosabban: biztos-e, hogy Ágnesnak egyszerüen csak nem tetszett ez a könyv? „Tudom, hogy depressziós volt, tudom, hogy öngyilkos lett. A Nincsteleneket olvasva ezt megértem. Több regényét nem ismerem. Ezek után illenék megismerkedni velük.”3 Most Ágnes éppen ért valamit. S ebből levon egy következtetést, melyet sem a szerző depressziójának, sem öngyilkosságának ténye nem indokol. Miért is illenék ennek az öngyilkos depressziósnak egyéb regényeivel megismerkedni, ha egyszer ez az - Ágnes szerint leginkább „az etnográfia vagy szociográfia müfajába” sorolandó - „regénye”4 valójában, számára legalábbis, nem szerethető. Itt valami nem stimmel.

Azzal kezdi, hogy a könyv „hivatalosan” ugyan egy regény, de nem az. Önéletrajznak is tekinthető lenne, de az sem - mondja. A könyv persze sem „hivatalosan”, sem másképpen nem regény. A fülön három bekezdés található, mind a három azzal kezdődik, hogy „A könyv...”. Szó sincs regényről. Persze önéletrajznak (is?) tekinthető lenne, de a szerző e vonatkozásban is pontos felvilágosítással szolgál a fülön. „A könyv életrajzi alapú, tehát korlátozott fikció."

\footnotetext{
${ }^{1}$ BorbéLy Szilárd, Nincstelenek: Már elment a Mesijás?, Pozsony - Bp., Kalligram, 2013. (A kötetből vett idézetek oldalszámait a továbbiakban a föszövegben, zárójelben közlöm. - V. M.)

${ }^{2}$ Heller Ágnes, Olvasónapló 2014-2015, Bp., Múlt és Jövő, 2015, 33-35.

${ }^{3}$ Uo., 35.

${ }^{4}$ Uo., 34.
} 
Nem kötözködöm tovább, s nem is szerettem volna kötözködni. Csak azért volt fontos számomra, hogy Heller naplóbejegyzését szemügyre vegyem, mert az a gyanúm támadt, hogy nemcsak ő, aki kvázi elutasítja a könyvet, hanem azok a bizonyos „mindenki” és „mások”, akiknek tetszett a könyv, azok is egészen másképpen tekintenek rá, mint én. Én ugyanis - erről írtam már másutt is - semmiképpen sem tekintem sem regénynek, sem életrajzi töredéknek, sem etnográfiának, sem szociográfiának (de miért is kell egy írásmüvet feltétlenül besorolni valami kategóriába?), hanem egy olyan nagyon is sajátos „könyvnek” tekintem, melynek írója azzal kínlódik, hogy megértse, mitől lett ö - vagy volt már kisgyerekkorában is - más, mint a többiek. ${ }^{5}$ Merthogy ő más, nem az az átlagos parasztgyerek, aki a hatvanas-hetvenes évek Magyarországán, egy isten háta mögötti kis faluban vált felnőtté: ennek nemcsak ő volt tudatában, hanem kivétel nélkül mindenki, aki valaha is kapcsolatba került életmüvével és személyével. Az a gyanúm, hogy Borbély Szilárd egész életében ezt a rejtélyt szerette volna megfejteni. Félre ne értsenek: Borbély Szilárd nem azt kérdezi, hogyan lett belőlem ismert és elismert író és irodalomtudós, amikor olyan mélységes mélyről jöttem. A társadalom alsó rétegeiből származó társadalmi elismertséget élvező értelmiségiek közül bizonyára sokan felteszik maguknak ezt a kérdést. Meggyőződésem azonban, hogy Szilárd valahogyan másképpen tette fel magának az életét meghatározó kérdést, olyan formában, hogy már magát a kérdést is nehéz megfogalmazni, választ adni rá meg nem művészi eszközökkel egyszerűen lehetetlen. Ha egyszerüen felsorolja a családját a falu lakosaitól elidegenítő tényezőket, maga is csak egy vállrándítással reagálhatott volna a „magyarázatra”. Neki muszáj volt belebújni kisgyerekkori bőrébe, méghozzá kisgyerekkorának különbözö és eltérö pillanataiban, hogy elszámolhasson magának és nekünk, olvasóinak valami nagyon mély és súlyos traumáról, melyet sehogyan sem tudott feldolgozni, s így életképtelenné tette őt. „Tudom, hogy depressziós volt, tudom, hogy öngyilkos lett. A Nincsteleneket olvasva ezt megértem.” A fentebb említett írásomat így fejeztem be:

Nem ragozom tovább. A Nincstelenek a másságról szól. A másságról a szegénységen belül. Arról, hogy a szegények többsége éppoly kegyetlenül konform, mint bármely más embercsoport többsége. »De ez nem biztos. Semmi sem biztos. Az sem, hogy van-e valóság vagy csak a számok vannak. ${ }^{6}$

Nos, bár én magyarázattal próbáltam szolgálni azt illetően, hogy miről is szól ez a könyv (ott én is regénynek neveztem; ki tudja, miért van az emberben ez a besorolási igény?), ez a magyarázat azonban - jó, legyen, a másságról szól - nagyon kevéssé elégítené ki Ágnest, ettől még nem értené, hogy azok a bizonyos mindenki és mások, s láthatóan én is, miért szeretik, szeretjük ezt a könyvet. Nem vitás, hogy egy bornírt és reménytelenül elmaradott falusi közösség azokat, akiket, ki tudja miért, zsidónak tekint, kilöki

\footnotetext{
${ }^{5}$ VAJDA Mihály, Vajon a szegénységröl szól-e Borbély Szilárd regénye?, 2000, 2015/11, 69-70.

${ }^{6}$ Uo., 69.
} 
magából (bár ez láthatóan kevésbé vonatkozik Mózsira, mint a kisfiú alapjában csupán zsidónak tekintett családjára): pontosan úgy, ahogyan elzárkózik a faluban élő cigányoktól is. De ha ez így volt, és bizonyára így volt Borbély Szilárd meg nem nevezett szülőfalujában is, miért nem írja le a szerző szisztematikusan az idevágó tényeket ebben az „etnográfiában” vagy „szociográfiában”, miért nem próbál utána járni annak, hogy vajon mennyiben specifikus ennek a falunak a viszonya az idegenekhez, mindazokhoz, akik nem „parasztok”. Mintha ebből a zsidók vonatkozásában felsejlenék valami a könyvben - rossz a „parasztok” lelkiismerete, minthogy nemcsak hogy egyetlen szó tiltakozásféle sem hagyta el ajkukat, amikor 1944-ben elhurcolták a zsidókat, s elhurcolásuk után (valószínünek tünik, hogy egyetlen családról van szó) azonmód ki is rabolták a zsidók házát, miközben az eldugott kincseket keresték, elvittek minden mozdíthatót. Nehéz lenne erről jó lelkiismerettel beszámolni Mózsinak, az egyetlennek, aki visszajött a munkaszolgálatból. A cigányokat meg ők is csak annyira utálják, amennyire mások is. Nem, a könyv nem sorolható az etnográfia vagy szociológia műfajába.

Hogy mindazt, ami a könyvben lejátszódik, egy kisfiú meséli el, s egyáltalán nem azzal a szándékkal, hogy beszámoljon a falujáról, azt sem Heller Ágnes naplóbejegyzéséből, sem az én rövid esszémből nem tudja meg az olvasó. Ágnes annyit mond, hogy „[1]ehetséges persze, hogy a szerző kisfiú korában egyet s mást megélt az itt leírtak közül, de csak egyet-mást, minthogy a történet szereplői nehezen azonosíthatók"? Én meg:

a kisfiú narrátor a maga életének csak egy igen rövid időszakát idézi fel (a Kicsi születésétől haláláig, majd a faluból való elköltözésükig, ha itt-ott visszaugrik is az időben). Lehet persze a regényt úgy tekinteni, mint ami egy kisgyerek szemével mutatja be a nincstelenek faluját; Borbély Szilárd a könyvben névtelen szülöfaluját...8

Nos: ez így szamárság. A könyv sem nem a nehezen azonosítható szereplőkről, sem a kisfiú életének egy szakaszáról, sem nem a szülőfalujáról szól, hanem magáról a kisfiúról. A kisfiúról, a gyerek Borbély Szilárdról, akit az író Borbély Szilárd - megeshet pszicho-terapeutikus céllal - felidézi önmagának, a pszichoterapeutájának, olvasóközönségének: értsem meg, értse meg kedves terapeuta, értsétek meg kedves olvasóim, az a radikális másság, amit bárki, akivel valaha is, mindegy, hogy milyen minőségben érintkezésbe kerültem, megérzett bennem, rajtam, az nem valami lemosható máz; ez a másság minden pórusomba beivódott, minden és mindenki, ami-aki körülvett engem kisgyerek koromban, ezt sulykolta belém. Így most megpróbálom megérteni, miképpen lehetek képes distanciát teremteni nemcsak az idegennek érzett világhoz, hanem ahhoz a valamihez is, ami belém ivódott és elidegenít a világtól. Azt hiszem, Szilárdnak végül is sikerült megértenie, amit megérteni próbált. Hogy ugyanis ő, Borbély Szilárd, az író, ezt a distanciát

\footnotetext{
${ }^{7}$ HeLLER, i. m., 34.

${ }^{8}$ VAJDA, i. m., 70.
} 
nem képes megteremteni. Viszont amíg a kisfiúval való azonosságát fel nem számolja, nem képes tovább élni sem. Akinek kezébe kerül maga a könyv, kérem, nézze meg a könyv borítójának hátsó fülén a kisgyerek Borbély Szilárd fényképét, majd keressen rá a Wikipédiában a Borbély Szilárd címszóra. Az utóbbi helyen számos fényképet fog találni az íróról. Egy ünneplőbe öltözött kis parasztfiú (pedig: „Mi nem vagyunk parasztok!" - 117.), s egy nagyvárosi intellektuel. Mármost melyik vagyok én? - kérdezi a felnőtt író. Képtelen vagyok összerakni magamat. Így élni pedig nem lehet. Heller Ágnes mégiscsak megértette a könyv üzenetét. Nem az etnográfiáét, nem a szociográfiáét, mert ha az lenne, vagy valami azokhoz hasonló, abból depresszió és öngyilkosság nem következnék; de Ágnes mégis a könyvet olvasva értette meg, hogy Szilárd depressziós volt és öngyilkosnak kellett lennie.

Még mielőtt félreértenének - már utaltam ilyesmire -, nem állítom, a Nincstelenek sem állítja (de hiszen a könyv nem is állít semmit!), hogy a szinte elviselhetetlen szegénység-nincstelenség, a rémes rokonság, a hisztérikus anya, az alkoholista apa, ez lenne a depresszió forrása. Ha viszont az érthetetlen-felfoghatatlan utalásokról beszélünk, hogy az apa valami zsidónak a zabigyereke volna (igen, az utalások érthetetlenek, felfoghatatlanok, nem azért, mert az apa még azt sem akarja elfogadni, hogy ez igaz lehet, ugyanakkor „Apám leveszi a szekrény tetejéről a kalapot. Fejére teszi. Feláll, a kezét kiterjesztve elmondja az áldást. Rosszul tudja, mert nem tanították meg neki. Csak ahogy hallotta gyerekként" - Mikor? Hol? Sabeszgójként?, mert az volt a zsidóéknál - „félreértve a szavakat, úgy mondja. Aztán megesszük, amit a föld adott és a szavak megszenteltek". (315.) Az anya elhiszi ugyan, hogy a férje a zsidótól van, de az unosuntalan megismételt „Mi nem vagyunk parasztok” - hát akkor kicsodák-micsodák? - nem arra lyukad ki, hogy ők zsidók: „»Oszt nem mindegy? Azt játsszuk, hogy zsidók vagyunk«, mondja anyám. »Gyorsan, tedd fel az apád ünneplő kalapját«, mondja. Leveszem a sifon tetejéről apám fekete kalapját. Apám egyébként jambót hord. Hétköznap csak pantallós ember visel kalapot. Meg a zsidók. De már nincsenek zsidók.” (214.) Vagy arról, ami nem érthetetlen, de ép ésszel felfoghatatlan, ahogy a falu lakosai végignézik, amint szekéren elhurcolják a zsidókat, akiket megkönnyeznek, de a szekér épp, hogy csak eltűnt a dombok mögött, máris kirabolják a házukat, míg az elrejtett kincsek után kutatnak.

Fulladok, ha zsidókról beszélnek. Ha a zsidó szót hallom, összeszorul a torkom. Kapkodom a levegőt. A fülem zúgni kezd. Észre fogják rajtam venni. Félek, hogy elárulom magam. Igyekszem úgy viselkedni, mintha egyáltalán nem érdekelne. A szívem a torkomban dobog. Ilyenkor nem veszek levegőt. Egy ideig nem szabad lélegeznem. Tudom, hogy nem sokáig tart ki a levegőm, de addig nem moccanok. Nem merek levegőt venni. A füleim égnek. Biztosan látszik is. Tükörben meg kellene néznem. Félek, hogy elárulnak a füleim. A zsidókról szoktak beszélni. A szavak tele vannak fenyegetéssel. Félek a szavaktól. (196.) 
És hát a kisfiú családja nemcsak zsidó vagy valami zsidóféle, hanem rutén is (hucul), meg román is, ahogy a falu fele az, jóllehet megtiltatott, hogy azok legyenek, s románul nem is tudnak egy szót sem, a kálvinista templomba meg be nem tehetik a lábukat (hiszen csak „bekerültek”), az ortodox, magukkal hozott erdélyi fatemplom viszont porig égett...

Mindez ott van a kisfiú fejében, szétbogozhatatlanul, csakhogy a felnőtt Borbély Szilárd identitásának felépítéséhez ezt a bogot szét kellene szálazni, de lehetetlen. Hiszen a felmenők fejében is ugyanaz a zürzavar uralkodik, mint az övében. Ezért is kell a kisfiúnak, $s$ talán a felnőtt írónak is a prímszámokkal eljátszania. Ott ugyanis rend van, a számok nem kiismerhetetlenek és nincsenek tele fenyegetéssel, mint az emberek. „Amikor kevesen vannak az utcán, nem félek annyira. Én az ismeretlentől félek jobban. Az emberektől." (150.) Miután elköltöztek, a közben nagyra nőtt kisfiú megtalálta a régi házuk tervrajzát.

\begin{abstract}
„A múltkorában megtaláltam a dobozban. Megtetszett. Tiszta és egyszerü rajz", mondtam.

„Mi értelme? Mi nem vagyunk rajta, csak az üres szoba. Nincs rajta semmi, ami velünk történt..."

Lehet, hogy ez tetszett meg benne. Hogy csak számok és vonalak voltak rajta. [...] Jobban meggondolva, nem is tudom, miért akartam egy tervrajzot bekereteztetni. Talán tényleg az tetszett, hogy nem vagyunk rajta a rajzon. Hogy egy ideális séma, amelyben minden tökéletes. (322-323.)
\end{abstract}

De miért is nem tetszett Ágnesnak a könyv? Végül is nem tudom. Lehet, hogy nekem sem tetszik. De másodjára is izgalommal olvastam végig.

\title{
MiHÁly VAJdA
}

Who knows what kind of book Nincstelenek [The Dispossessed] is and what it is about

The author of this essay looks at the book Nincstelenek, as something very special; the author of the book struggles with himself, because he wants to understand why he has been different from everybody else from his childhood. He must re-createhis childhood self to be able to give account about a very deep and severe trauma he could cope with any means. He wants to understand himself at last. He tries to create a distance from his childhood self, and from the world where he felt alienated as a child. Lacking that distance he could not live further. But not even the prime numbers could help him, though there is an exact order among them; and the design of the old house could not help him either. Szilárd Borbély was not able to stop the confusion of his life. 